\title{
ОЧАРОВАНИЕ КУКАЫ
}

Смышляева Алена Александровна

Комлекционер, эксперт в сфере

антиквариата и колмекционной

живописи, руководитель аукционного

Аома «Oriental art».

Россия, г. ВАаАивосток.

alena_alekss_@mail.ru

\section{Аннотация}

В статье представлен обзор выставки кукол конца XIX - начала XX века, которая состоялась с 12 февраля по 21 апреля во ВАадивостоке в Аоме семьи Сухановых (филиал Приморского государственного объединенного музея им В. К. Арсеньева). В экспозиции были представлены куклы производства Франции, Германии, России, Италии, Японии и Китая. Все экспонаты - из частной колцекции антикварных кукол, очень редких Аля Аальневосточной части России.

Ключевые слова: антикварная кукла, частная колцекция, Франция, Германия, Россия, Италия, Япония, Китай.

\section{Библиографическое описание Аля цитирования:}

Смышляева А.А. Очарование куклы // Искусство Евразии. - 2019. - № 2 (13). C. 217-227. DOI: 10.25712/ASTU.2518-7767.2019.02.020. [Электронный ресурс] URL: https://readymag.com/u50070366/1431023/31/

В мемориальном доме-музее семьи Сухановых во ВАадивостоке в 2019 году состоялась выставка «История кукцы», на которой было представлено около 30 старинных кукол конца XIX - начала XX века и всевозможных аксессуаров к ним из частной колмекции автора статьи (А^ены Смышляевой - прим. ред.). В настоящей статье представлен обзор выставки, анализ техник и технологий изготовления куко указанного периода с привлечением данных зарубежных каталогов [1; 2; 3].

Существование такого рода колмекции на Аальнем Востоке России Аает возможность приобщиться к европейской культурной традиции. Большинство экспонатов выставки выполнены из бисквитного фарфора. Это технология производства фарфора, исключающая покрытие изделия глазурью. Аругими словами, это неглазурованный фарфор - характерный материал Аля большинства кукол второй половины XIX века.

Со времени раскрытия секрета получения фарфора в Европе, в Германии, в самом начале XVIII века начинается активное развитие производства фарфоровых изделий в этом регионе. В Аальнейшем этот материал стал применяться и в производстве промышленных кукол. Первые фарфоровые куклы имели матерчатое или кожаное тело 
в сочетании с фарфоровыми конечностями и головой. В широкий обиход такие куклы вошли с середины XIX века.

Большинство кукол из колмекции имеют шарнирные (подвижные) тела, характерные Аля второй половины XIX века, выполненные из папье-маше и дерева.

Начиная с 1840 года фарфор, покрытый глазурью, широко применяется в кукольном Аеле в крупных европейских центрах керамического производства, таких как Аимож, Мэйсен, Аимбах (рис. 1 и 2).

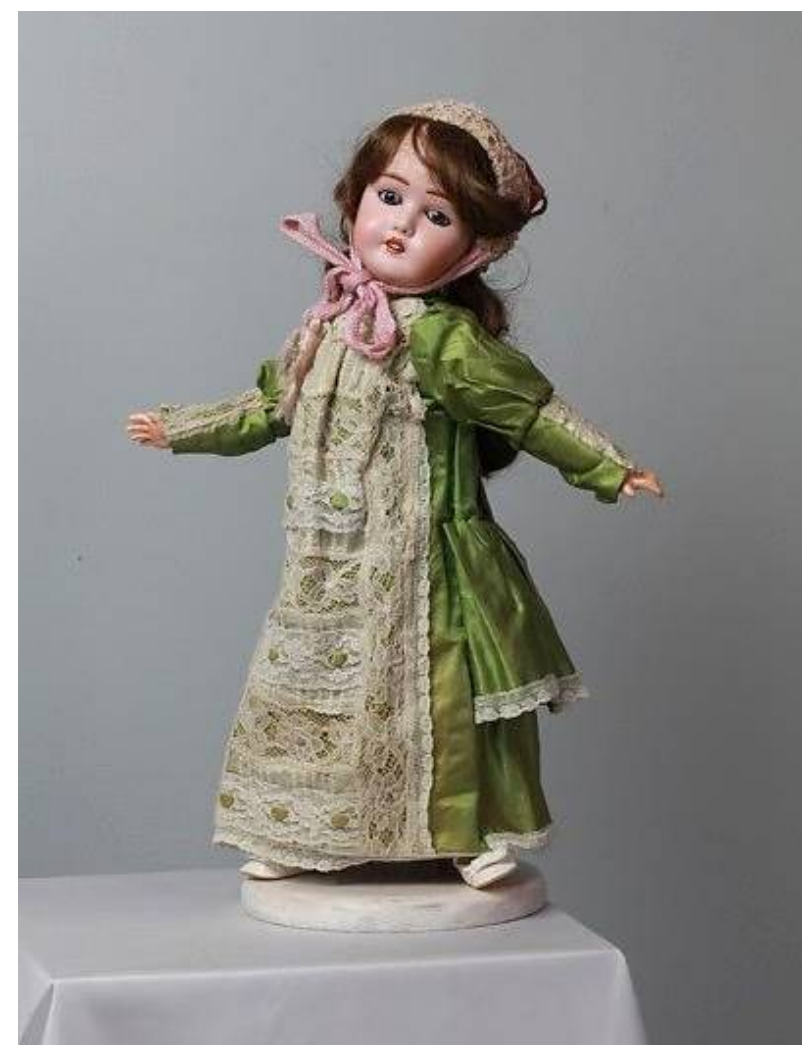

Рис. 1. Кукла. Конеи ХIX - начало XX века. 1имож (Lemoges), Франиия. Частная коллекиия A.А. Смыгиляевой.

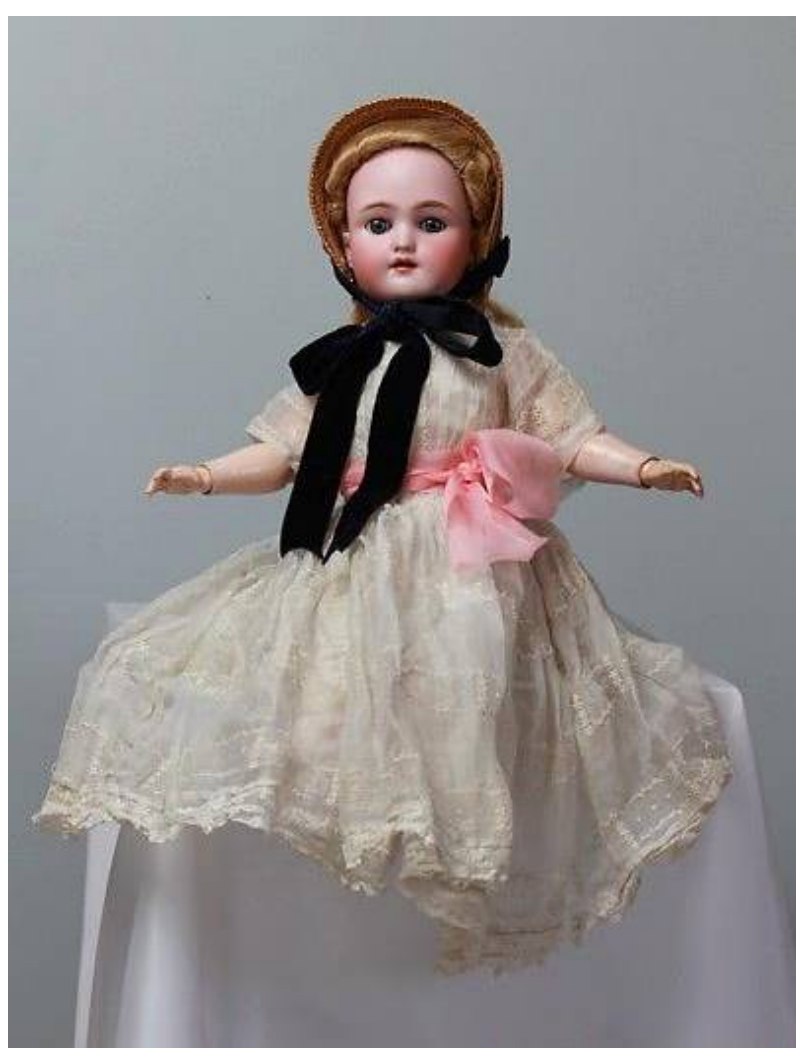

Рис. 2. Кукла. Конеч XIX - начало XX века. Шунау и Хоффмейстер, Германия. Частная коллекиия А. А. Смицияяевой.

Изначально головы кукол отливали полностью из фарфора, а волосы и глаза были нарисованными. Часто также обувь куклы рисовалась на ее ножках. Отливку головы, а также ручки и ножки покрывали глазурью. ГАазурь придавала деталям куклы глянцевый блеск. Голова делалась вместе с шеей и плечами и была неподвижной. Роспись кукол в этот периол была подглазурной. Впервые в истории кукольного дела подвижная шея была применена в 1858 году.

Со временем глазурь перестают применять в производстве головы кукол. А позднее головы подкрашивают в телесный цвет. Сама структура бисквита придавала куклам благородную эмегантность и утонченность.

Бисквитный фарфор как наиболее подобный по внешнему виАу цвету живого Аица становится веАущим материалом в производстве кукол. Именно с ним начинают работать прославленные мастера кукольного дела во Франции: Жюмо, Готье, Штайнер, Брю. Также он получает широкое распространение в Германии (Арманд Марсель, 
Хойбах, Камер и РейнхарАт, Шунау и Хоффмейстер, Симон и Хальбиг). Многие куклы, составившие основу выставки, принадлежат производству этих фабрик.

Именно в бисквите создавались кучшие образцы кукол, которые сейчас явцяются украшением музейных и частных колмекций.

Внешний виА кукол претерпевает значительные изменения во второй половине XIX века. На смену нарисованным глазам сначала приходят стеклянные стационарные глаза, это стало возможным, когда при производстве головы кукцы срезался верхний слой и тем самым открылся Аоступ в голову кукцы Аля установки глаз. Затем их заменяют подвижные (спящие) глаза. Срез головы куклы теперь закрывается париком. Парики выполнялись из натурального волоса, мохера.

Аидером технических новаций являлась фирма Брю (Франция), основанная в 1866 году. Именно ей принадлежал 21 патент на изобретения, предназначенные на усовершенствование куклы.

Б^агодаря труду мастеров-кукольников второй половины XIX - начала XX века кукца приобрела свой прекрасный и привычный сегодня внешний виА. Именно в этот период были изобретены все нововведения, коснувшиеся как внешнего вида кукол, так и их устройства. Все эти изобретения до сих пор применяется в их производстве.

Куклы рассматриваемого периода стали более реалистичными. Аидерство в производстве принаАлежало французским и немецким мастерам. Отличительной чертой французских кукол является элегантность и роскошь. Нарядные красавицы с выразительными глазами, прекрасными прическами, шляпками, сережками и Аругими изящными аксессуарами покоряли с первого взгляла Аетей и взрослых.

ОАной из старейших мануфактур, производившей кукольные головы Аля кукол, считается предприятие Готье. Оно было основано в Париже в 1860 году. Через семь Ает фабрикой был запатентован метод разрезания бисквитных голов Аля вставления внутрь стекцянных глаз.

ОАни из Аюбимейших колмекционерами французских кукол принадлежат производству Казимира Брю (Bru). Это удивительно хорошенькие и мегкоузнаваемые куклы с задумчивым взглядом огромных глаз. Непревзойденное качество продукции мануфактуры подцерживалось и при следующем владельце. Но справиться с нарастающей конкуренцией немецких кукол у нового владельца не получилось.

КукАы другого знаменитого французского мастера Эмиля Жюмо (Jumeau) выглядят более утонченно. Их отличает немного вытянутый овал мица и огромные грустные глаза. Высокий уровень исполнения, великолепные наряды и очаровательное выражение мица - эти отличительные черты кукол Жюмо обеспечили ему репутацию величайшего кукольного мастера. И несмотря на то, что он в своей работе ориентировался на покупателей среднего класса, куклы продолжали оставаться очень Аорогими. На выставке французские куклы представлены работами мастеров не только фабрики Жюмо, но и $\mathrm{SFBJ}$ и Аимож.

Немецкая фарфоровая кукца, отличающаяся большей практичностью, является основой колцекции, представленной на выставке. Немецкие кукольники, внимательно следившие за успехом французов, постоянно перенимали опыт и совершенствовали свою продукцию, отвергая однако сразу то, что относилось к роскоши или оказывалось Аорогостоящим. В результате этого подхода немецкая кукла становится практичнее. Они 
не выгодно отАичались простыми и грубыми телами, менее нарядными одеяниями, одинаковыми выражениями Аиц, а иногАа и примитивностью росписи Аица.

Исполнение кукол иногда было Аалеким от миловидности. И тем не менее, Германия, придерживаясь выбранной стратегии, смогла значительно снизить цены на кукольную продукцию. В результате этого рос спрос на немецкие куклы. В том числе и за пределами страны. По статистике, только 5 процентов от всего объема произведенных к концу XIX века немецких кукол относилось к числу дорогих.

Наиболее известным немецким производителем кукол была мануфактура Симон Халбиг (SimonHalbig) (рис. 3 и 4). Фарфоровые головы этой фабрики заказывали даже французские кукольники. Кукла этой мануфактуры, представленная на выставке, имеет «шагающий» механизм (аналогичная кукца хранится в Музее Аондона).

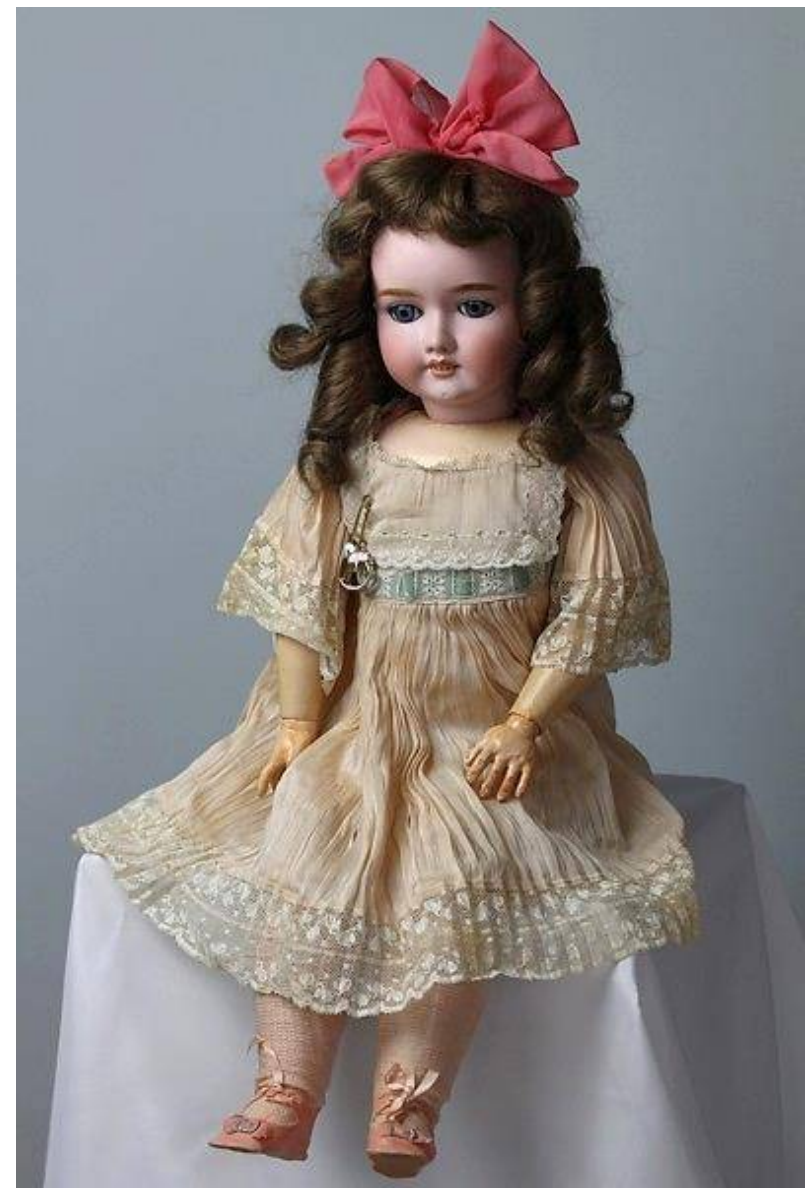

Ри. 3. Кукла мануфактурь Симон Халбиг (SimonHalbig). Конеи XIX - начало XX века. Германия. Частная коллекиия А.А. Смицияяевой.

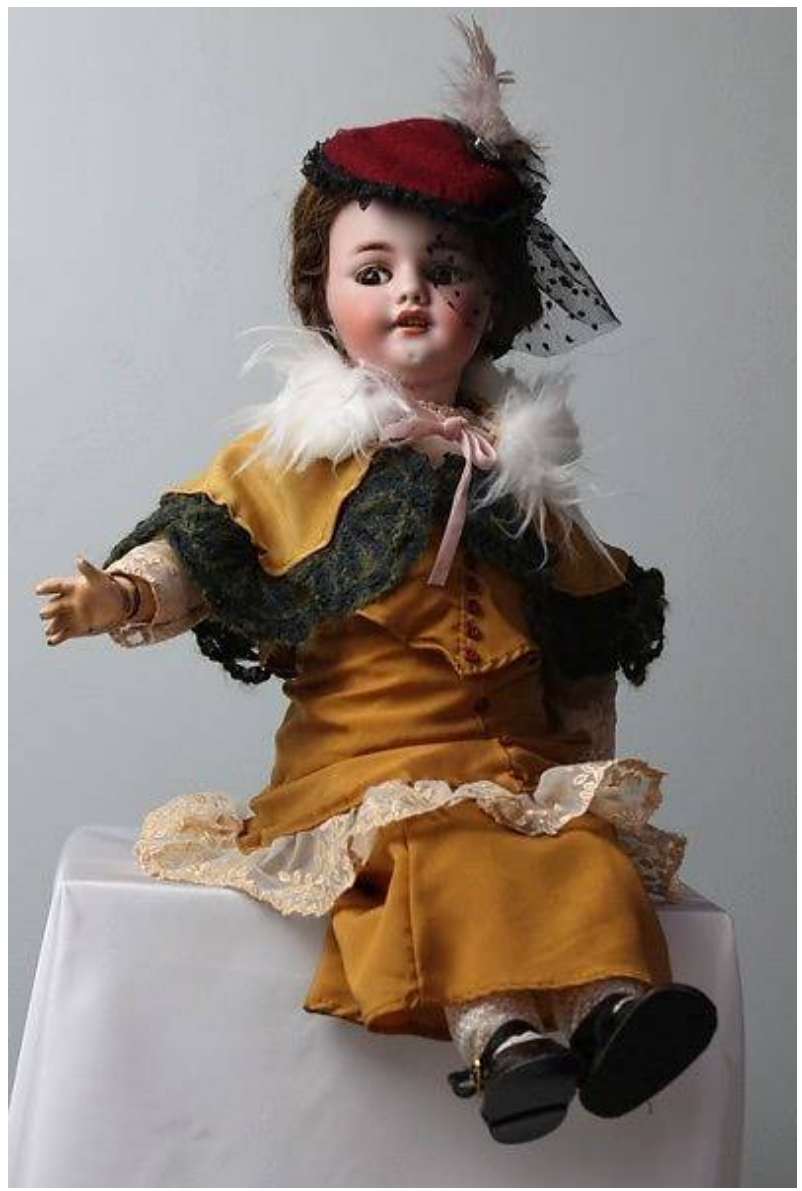

Рис. 4. Кукла мануфактури Симон Халбиг (SimonHalbig). Конеч XIX - начало XX века. Германия. Частная коллекиия А. А. Смициляевой.

Еще одним из достижений германской кукольной промышленности стало быстрое приспособление к меняющимся потребностям общества. Как только в Европе на рубеже веков меняется отношение к детям, возрастает интерес к психологии ребенка, начинается массовое производство куко -младенцев. 
В 1909 году начинают появцяться первые куклы, похожие на младенцев. А в 1920-м одним из самых продуктивных производителей кукол стал Арман Марсель (Marseille), зарегистрировавший патент на кукцу «Пупс - моя мечта». Марсель был самым крупным и плодовитым фабрикантом. Его фабрикой выпущено несколько милАионов голов из бисквитного фарфора. Все куклы имели совершенно неповторимое выражение Аица, нежное, Аоброе, абсолютно живое. Фабрика проработала более полувека. Неудивительно, что кукол именно этой фабрики можно часто встретить в большинстве комлекций антикварных кукол.

На выставке также было представлено несколько кукол, выпущенных фабрикой Марселя (рис. 5-7). Также куклы производства Арманда Марселя можно встретить в Загорском музее игрушки (Сергиев ПосаА) и многих Аругих музеях России.

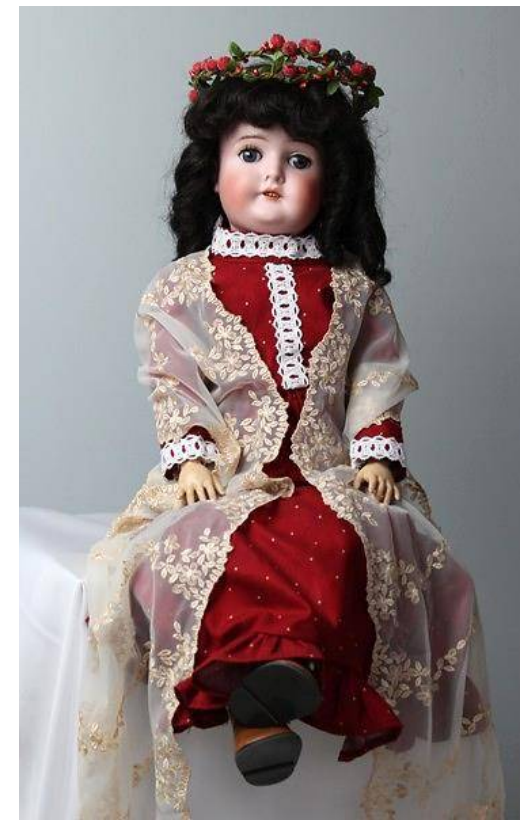

Рис. 5. Кукла производства Арманда Марселя. Конеч XIX - начало XX века. Германия. Частная коллекиия А.А. Смигиляевой.

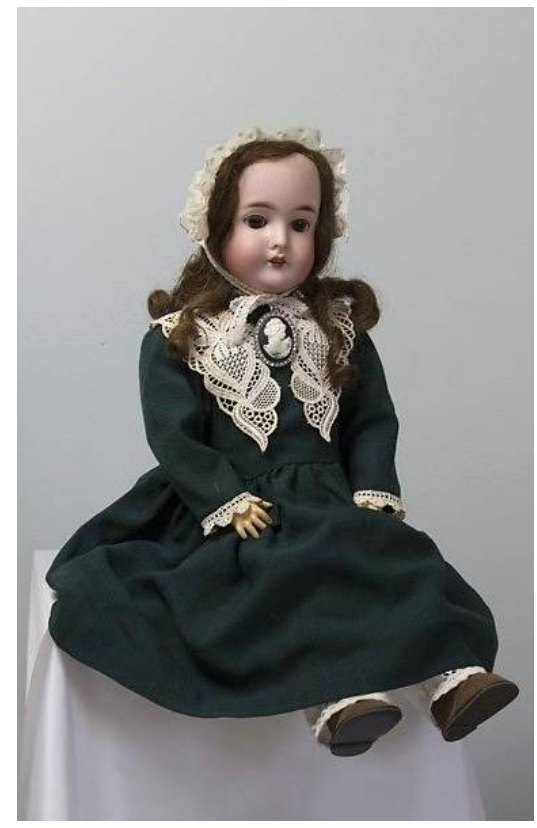

Рис. б. Кукла производства Арманда Марселя. Конеи XIX - начало XX века. Германия. Частная коллекиия A.А. Смицияяевой.

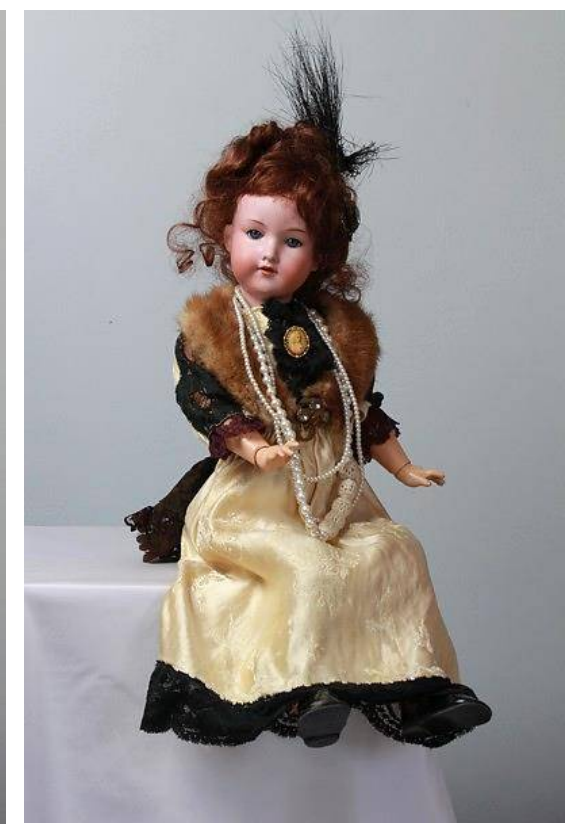

Рис. 7. Кукла производства Арманда Марселя. Конеи XIXначало ХХ века. Германия. Частная коллекиия A. А. Смыиияяевой.

Все более увлекал немецких мастеров-кукольников реализм. Ранее они уже ввели моду на рот с зубками. Правда, не все считают, что куклы выиграли в эстетическом отношении. ОАнако выпуск характерных кукол был налажен. Характерные куклы имели определенное выражение Аица (радость, гнев, плач). Но популярностью у детей такие куклы не пользовались. Ярким представителем характерных кукол на выставке является образец от Hertel, Schwab \& Co (Германия, 1912-1920-е гг., рис. 8). 


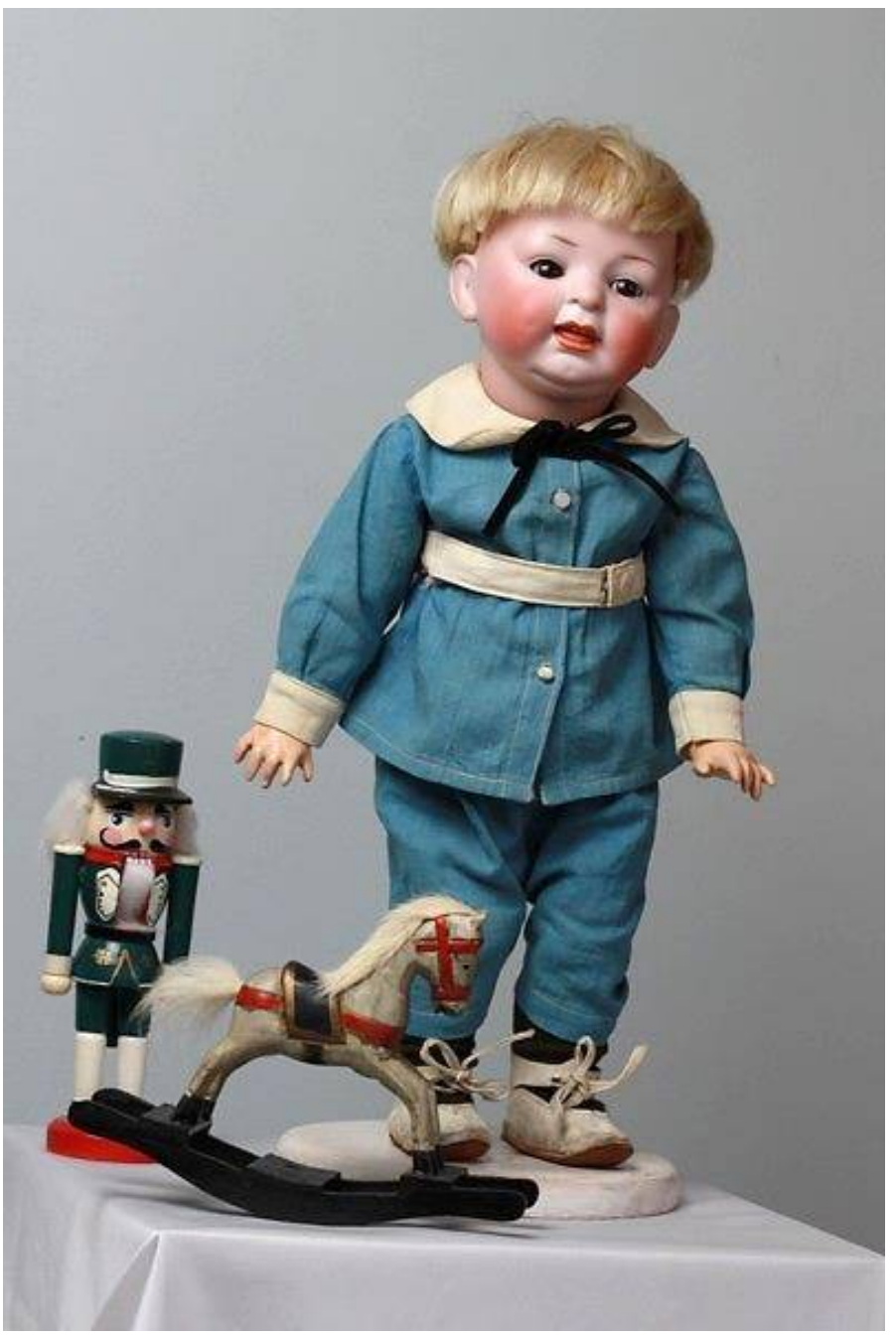

Puc. 8. Kyкла Hertel, Schwab \& Co.

1912-1920-е. Германия.

Частная коллекиия А.А. Смыгиляевой.

Приближалось время заката производства фарфоровых кукол. В периол между Авумя войнами кукольные мануфактуры переживали не кучшие времена, тем не менее, многие из них просуществовали еще довольно Аолго. Но время открывало все новые возможности и новые материалы. Постепенно все производители отказались от создания фарфоровых кукол в пользу более практичных материалов.

В настоящее время фарфор как материал Аля изготовления промышленных игровых кукол не употребляется в производстве.

Несмотря на то, что основу комлекции составцяют куклы с головой из бисквитного фарфора, Аля выставки были отобраны куклы, выполненные и в Аругих техниках и материалах, чтобы показать разнообразие видов кукол рассматриваемого периода. Среди экспонатов представлены войлочные Lenci, текстильные куклы артели «Всекохудожник», традиционные куклы из дерева Японии и Китая.

Франция на выставке представлена несколькими фабриками, в том числе куклами выдающегося мастера Эмиля Жюмо (рис. 9 и 10). Потомственный кукольник, он производил кукол в образе девочек, а не взрослых дам, начиная с 1880 года. Жюмо предпочитал сотрудничать не с ремесленниками, а с талантливыми скульпторами. Поэтому его куклы выглядят более утонченно с очаровательным выражением миц и с проникновенным взглядом огромных «грустных» глаз. 


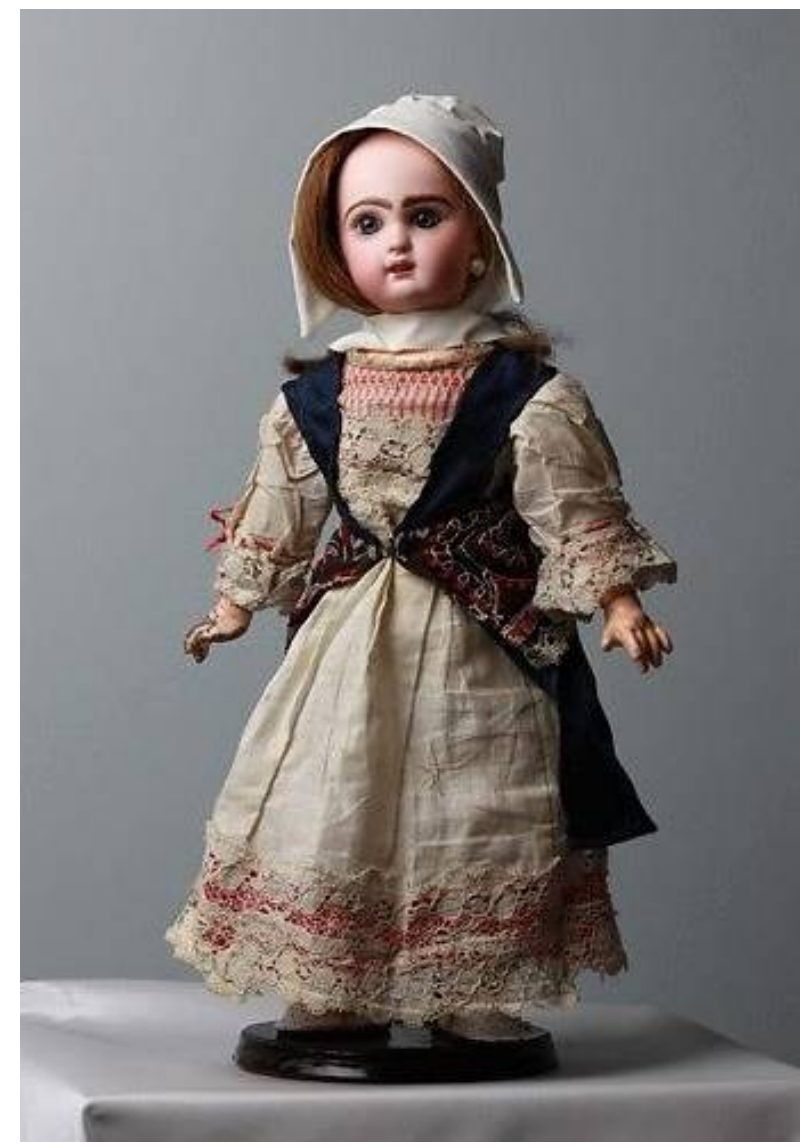

Ри. 9. Кукла Эмиля Жюмо. Конеч ХІХ в.

Франиия. Частная коллекиия А.А. Смыциляевой.

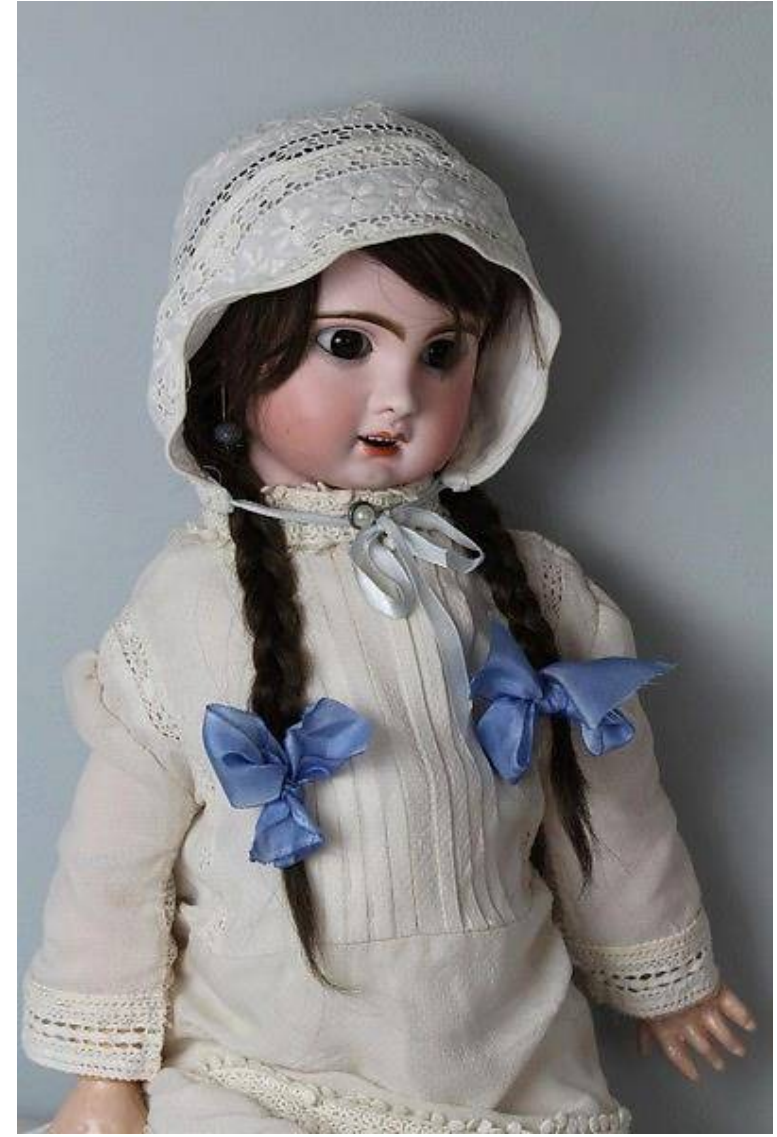

Рис. 10. Кукла Эмиля Жномо. Конеч ХІХ в.

Франиия. Частная коллекиия

А.А. Смышиляевой.

Под натиском германской конкуренции, наладившей выпуск менее дорогих кукол, французским производителям пришлось объединиться в Союз, начиная с 1898 года. SFBJ - аббревиатура объединения французских кукольных промышленников. Следствием этого был выпуск конкурентоспособных в ценовом вопросе, но и более простых в исполнении кукол (рис. 11).

Российские куклы, произведенные до 1917 года, являются большой редкостью. Промышленное производство кукол в России распространяется только в начале XIX века. Неудивительно, что и у детей в Российской империи куклы германского и французского производства были особенно распространены, об этом говорят многочисленные документальные свидетельства. В частности, сохранившиеся игрушки из царской семьи принадлежат производителям этих стран.

Но все же в колмекции имеется одна из российских кукол, относящаяся к 1910 году. Это кукла вылающегося российского фабриканта С.Г. Аунаева (рис. 12). В 1893 году он открыл при Митино собственную фарфоровую мастерскую, которая через некоторое время выросла до размеров небольшого завода и дава^а заработок почти всей Аеревне, жители которой занимались мепкой заготовок. Маленькие 30-сантиметровые куклы с фарфоровыми головами, одетые в народные костюмы разных губерний, появились еще в 1880 году. Головы Аля этих кукол изначально покупались за границей. Позже в целях удешевления производства покупные фарфоровые головки были заменены на отечественные фарфоровые фабрики Аунаева, а затем, в начале 1900-х - 
на терракотовые. Из-за хрупкости материала они Аибо не маркировались, Аибо ставился номер размера в сантиметрах.

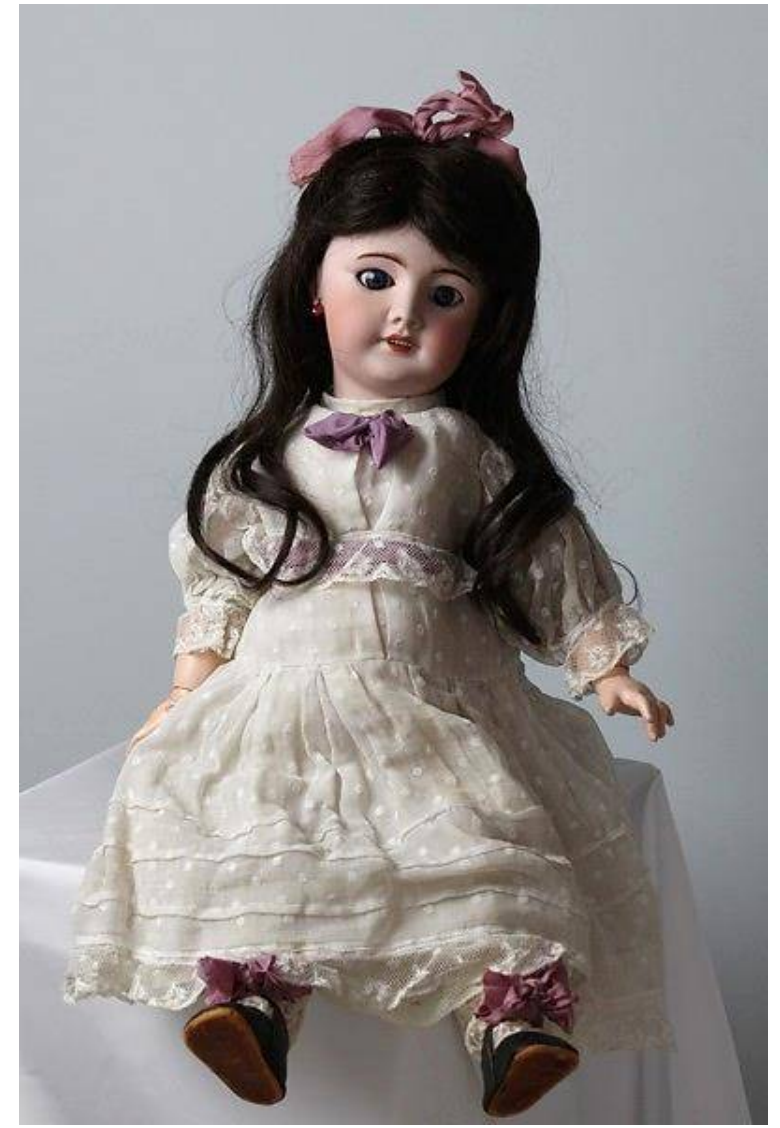

Рис. 11. Кукла производства объединения франиузских кукольньгх промышиенников SFBJ. Конеи XIX в. Частная коллекиия A.А. Смигиляевой.

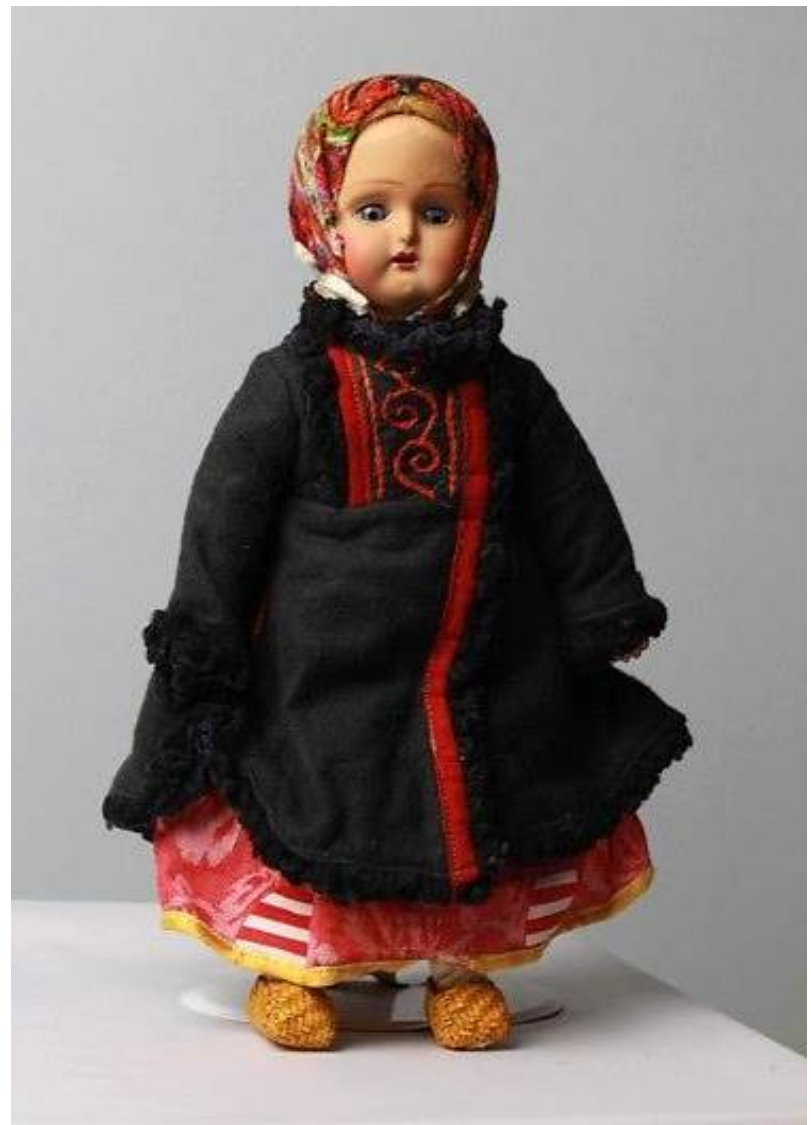

Рис. 12. Кукла в народном костюме. 1910.

Фабрика С.Г. Аунаева, Россия. Частная коллекиия A.А. Смыцияяевой.

Японские куклы, находящиеся в колцекции, выполнены в одной из традиционных техник. Несмотря на то, что в Японии существовали производители кукол с бисквитными головами, такие как Моримура бразерс и Ниппон, Аля выставки были отобраны куклы, наиболее отражающие самобытность Японии. Эти куклы с основой, выполненной из дерева, были созданы мастерами в начале прошлого века.

Кукца производства Китая 1900-х годов выполнена из дерева и представляет собой смешение техник производства японских традиционных кукол и кукол шанхайского благотворительного фонда (рис. 13).

Ярким отличающимся экспонатом выставки является кукца производства итальянской фабрики Lenci (Аенчи) 1926 года, выполненная из войлока (рис. 14). Этот материал характерен Аля производства кукол в Италии и некоторых Аругих регионах в этот период. Необычно живой взгляд и характер отличает итальянских кукол. Их Аица расписывались масляными красками. Туринская фабрика Lenci была основана в 1919 году в Турине и просуществоваца до 1985 года. 


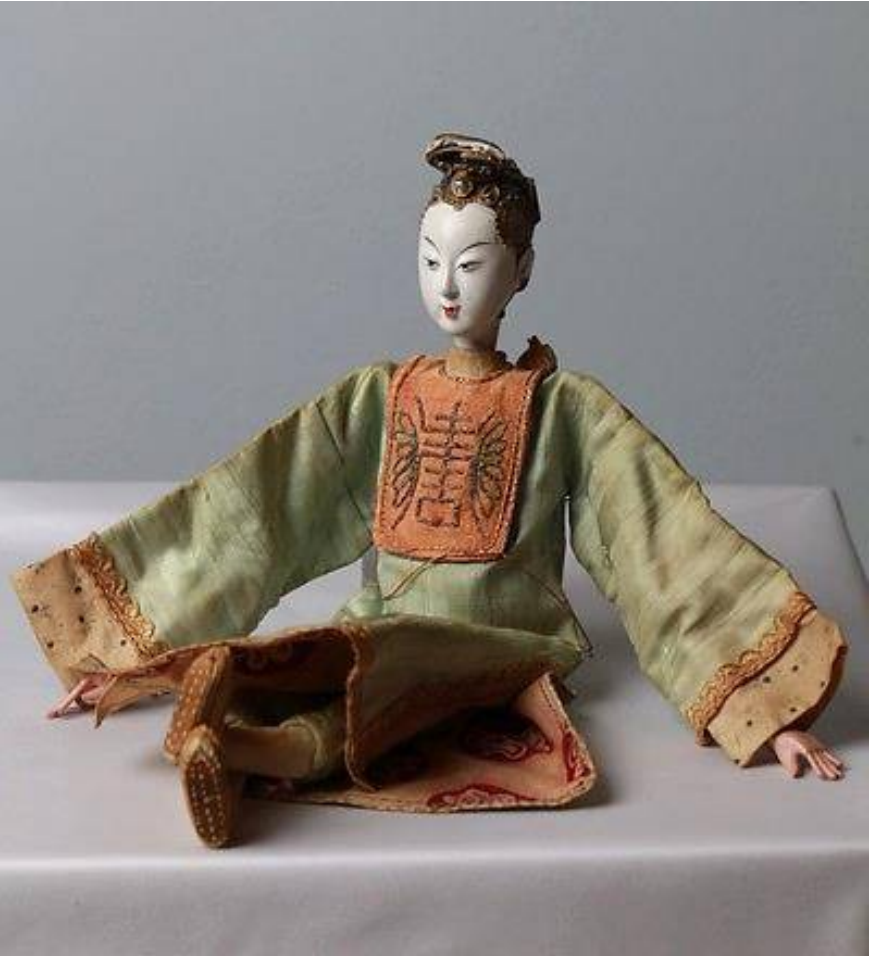

Рис. 13. Кукла из дерева. 1900-е. Китай. Частная коллекиия А.А. Смыгиляевой.

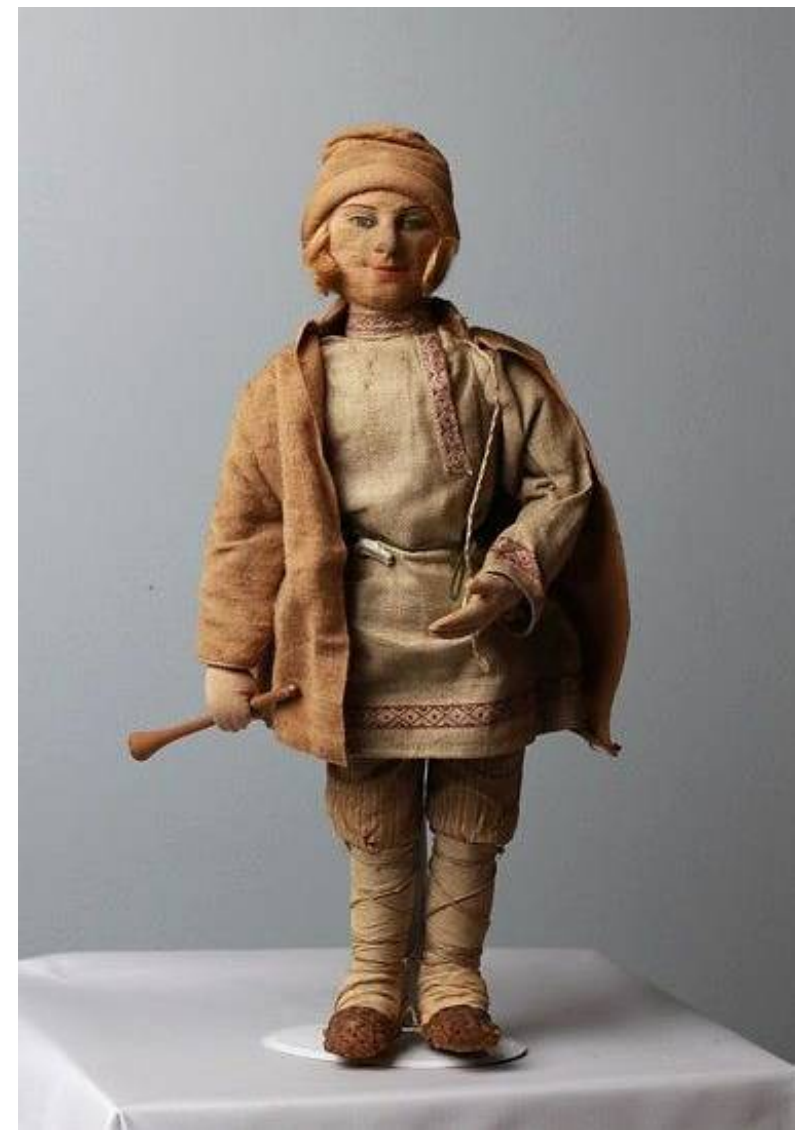

Рис. 15. Кукла «Пастух». 1930-е. Артель «Всекохудожник», Россия. Частная коллекиия А.А. Смыциявевой.

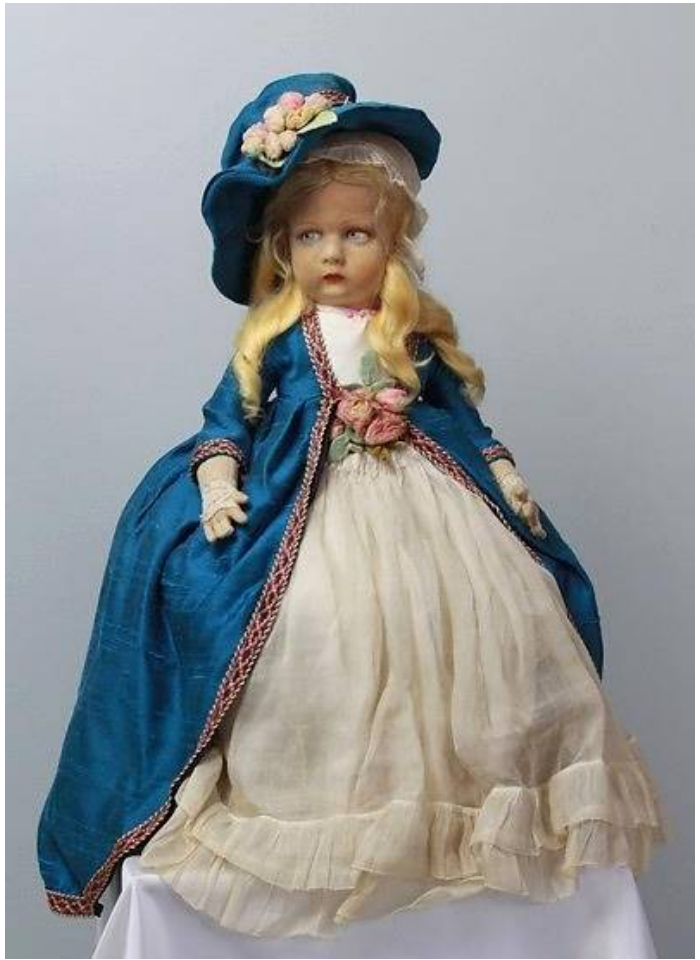

Рис. 14. Кукла из войлока. 1926.

Фабрика Lепсі (Лении), Италия.

Частная коллекиия А.А. Смицияяевой.

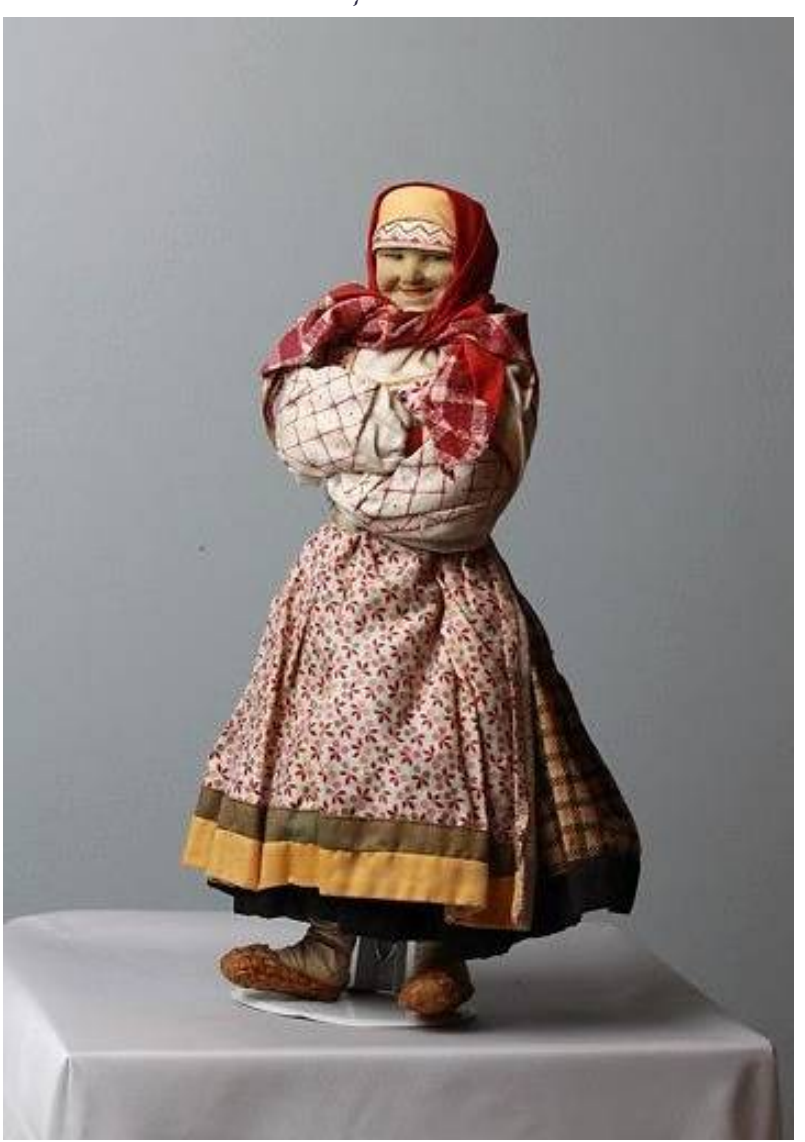

Рис. 16. Кукла «Рязанская женщина». 1930-е. Артель «Всекохудожник», Россия. Частная коллекиия А.А. Смыпиляевой. 
Присутствовали на выставке и текстильные куклы «Пастух» (рис. 15) и «Рязанская женщина» (рис. 16) из серии кукол в национальных костюмах, произведенные в России в 1930-х годах артелью «Всекохудожник». Среди многочисленных творческих групп, существовавших в Москве в 1920-е годы, вылелялась группа художников, собиравшихся в районе Нижней Масловки. Именитые мастера, среди которых были и такие уже известные, как Б. Кустодиев, В. Васнецов, а позже и А. Аейнека, творили сами и охотно обучали основам искусства Аругих. В 1928 году этот своеобразный кцуб получил формальный статус и стал именоваться «Всероссийский кооперативный союз работников изобразительных искусств», или сокращенно «Всекохудожник». В 1920 1930-е гг. активно занимались производством кукол на экспорт - это была серия куколок, представ яяюих народности респубиик СССР.

Аанная выставка колмекционных кукол - уже третья экспозиция из собрания автора (Алены Смышляевой - прим. ред.). Первая из них состоялась в 2017 году и прошла с большим успехом. На этот раз посетители увидели дореволюционных фарфоровых красавиц, по сей Аень сохранивших свое очарование и преАставляющих собирательский и искусствоведческий интерес.

\section{Митература}

1. Curtie T. Lyle price guide Dolls \& Toys. Lyle Publications, 1992.

2. Goodfellow C. Ultimate doll book. London, Dorling Kindersley Publishers Ltd., 1993.

3. Whitton M. The Jumeau doll. New York, Courier Corporation, 1980.

Статья поступила в редакцию 17.06.2019 г. 
DOI: 10.25712/ASTU.2518-7767.2019.02.020

\title{
THE CHARM OF A DOLL
}

Smyshlyaeva Alena Aleksandrovna

Collectioner, expert in the field of antiques

and collectible painting, manager of the

auction house «Oriental art».

Russia, Vladivostok.

alena_alekss_@mail.ru

\begin{abstract}
The exhibition of dolls of the late 19th and early 20th centuries was held from February, 12 to April, 21 in Vladivostok in the House of the Sukhanov Family (a branch of the Primorsky State United Museum of V. K. Arsenyev). The exhibition presented dolls made in France, Germany, Russia, Italy, Japan and China. All exhibits were provided from a private collection of antique dolls, very rare for the Far Eastern part of Russia.

Keywords: antique doll, private collection, France, Germany, Russia, Italy, Japan, China.

\section{Bibliographic description for citation:}

Smyshlyaeva A.A. The charm of a doll. Iskusstvo Evrazii - The Art of Eurasia, 2019, No. 2 (13), pp. 217-227. Available at: https://readymag.com/u50070366/1431023/31/ DOI: 10.25712/ASTU.2518-7767.2019.02.020. (In Russian).
\end{abstract}

\section{References}

1. Curtie T. Lyle price guide Dolls \& Toys. Lyle Publications, 1992.

2. Goodfellow C. Ultimate doll book. London, Dorling Kindersley Publishers Ltd., 1993.

3. Whitton M. The Jumeau doll. New York, Courier Corporation, 1980.

Received: June 17, 2019. 